\title{
Rabies transmission risks during peripartum - two cases and a review of the literature
}

\section{Running title: Rabies during peripartum}

Christiane Tshabu Aguèmon ${ }^{1 *}$, Arnaud Tarantola ${ }^{2 *}$, Eugène Zoumènou ${ }^{1}$, Sophie Goyet $^{2}$, Pamphile Assouto ${ }^{1}$, Sowath $\mathrm{Ly}^{2}$, Serge Mewanou ${ }^{1}$, Hervé Bourhy ${ }^{3}$, Betty Dodet ${ }^{4}$, and AbdouRahmann Aguèmon ${ }^{5}$

1. Centre national hospitalier et universitaire Hubert Koutoukou Maga (CNHU-HKM), Cotonou, Bénin

2. Institut Pasteur du Cambodge, Epidemiology Unit, Phnom Penh, Cambodia

3. Institut Pasteur, Lyssavirus Dynamics and Host Adaptation Unit, National Reference Centre for Rabies, WHO Collaborating Centre for Reference and Research on Rabies, Paris, France

4. Dodet Bioscience, Lyon, France

5. Professeur d'anesthésie réanimation, membre AfroREB, président ONG Association béninoise contre la Rage, Cotonou, Bénin

*Both authors contributed equally

Corresponding author:

Arnaud Tarantola, MD, Msc

Head, Epidemiology and Public Health Unit

Institut Pasteur du Cambodge

5, Bvd. Monivong

BP 983 - Phnom Penh

Royaume du Cambodge

Mobile: +855 (0) 12333650

Tel: +855 (0) 23426009 ext. 206

Fax: +855 (0) 23725606

Email: atarantola@pasteur-kh.org

Keywords : rabies; vertical transmission; peripartum transmission; rabies prevention; Postexposure prophylaxis; PEP

Summary 40 words: We report two cases of probable rabies in pregnant women and review 14 additional published cases. Mother-to-child transmission was confirmed in one case. PEP should be and can be safely administered to exposed pregnant or lactating women, and their infants. 


\section{Abstract [196 words]}

We report two cases of probable rabies in near-term/ at-term pregnant women in sub-Saharan Africa and Asia. One baby was delivered by caesarean section and the other one vaginally. Both received post-exposure prophylaxis (PEP), including RIG and vaccine and both are alive and healthy, at 9 and 24 months respectively.

We found 14 other published cases of infants born from rabid mothers. One confirmed case of rabies transmission occurred. The other children born from rabid mothers, with or without caesarean section, did not acquire rabies, and were still healthy at the time of reporting, with or without post-exposure prophylaxis.

Mother-to-child transmission of rabies is possible, but rare, because rabies virus is not present in blood and exposure of the baby's mucosa to maternal infectious fluids and tissue seems limited. A conservative approach should however, be adopted, and rabies PEP, including RIG, be administered as soon as possible to babies born from probably rabid mothers. Whether cesarean-section clearly provides prevention remains unclear.

Rabies can be prevented in pregnant women by PEP administration. Rabies cell-culture vaccines are safe and effective and can be administered to pregnant and lactating women, as well as newborns. Efforts must focus on raising rabies awareness in the general population, as well as in healthcare workers. 


\section{Introduction}

Rabies is a zoonotic and neglected disease caused by lyssaviruses, rabies virus (RABV) representing a major public health issue in endemic countries. Human infection usually occurs through a transdermal bite or scratch by an infected animal, a domestic dog in over $99 \%$ of documented human rabies cases (1). The incubation period is typically 1-3 months but may vary from $<1$ week to $>1$ year (2). RABV causes an acute, progressive encephalomyelitis. Although rare cases of survival have been reported in patients exposed to bat rabies who developed a vigorous, early immune response, rabies due to canine RABV is almost always fatal: attempts to treat symptomatic patients infected with dog RABV variants with therapeutics and intensive care support usually fail (3).

Prevention of clinical disease is nearly $100 \%$ effective, even after confirmed exposure to RABV: Post-exposure prophylaxis (PEP), consisting of immediate and extensive cleaning of the wound after exposure, and a course of vaccines meeting WHO recommendations, with rabies immunoglobulin (RIG) if indicated, is highly effective in preventing rabies, saving countless lives each year $(1,2,4,5)$.

Rabies remains prevalent in developing countries. According to recent estimates (6-8), canine rabies still causes around 59,000 deaths and over 3.7 million disability-adjusted life years (DALYs) each year; this is five times the fatalities reported during the 2004-2005 Ebola epidemic in West Africa (9). The greatest risk of developing rabies falls upon the poorest regions of the world, especially in rural areas of Africa and Asia $(1,6,8)$, where vaccination of domestic dogs is not widely implemented and where access to PEP is most limited or unaffordable for target populations (10).

It is inevitable that in such settings some victims bitten by suspected rabid animals will be pregnant women and that some will progress to rabies in the absence of timely and effective 
administration of PEP. Every rabies case is an avoidable tragedy, but when rabies occurs in a pregnant woman, the life of the future baby is also compromised. If rabies symptoms occur in an at-term pregnant woman - when nothing can be done to save the mother - the issue is whether and how the newborn can be saved. There are no relevant specific guidelines and little data to guide clinicians. We report two cases of probable rabies in at-term pregnant women and their outcome, one in sub-Saharan Africa and one in Asia. We have also reviewed and analysed the available data on similar cases, in an attempt to identify best practices in such situations.

\section{Case reports}

\section{Case 1 -Benin, Africa}

On 16 February 2015, a pregnant seamstress aged 25 (nulliparous primigravida), was referred to the Comé hospital, $80 \mathrm{~km}$ from Cotonou, the economic capital of Benin, for mental disorders of acute onset. She presented agitation, persecutory delusions, excessive sweating and hydrophobia. Thirty days earlier, she had been bitten on the left leg (Grade III exposure) by a puppy that had immediately been put down, without post-mortem laboratory testing for of canine rabies. The patient had received tetanus antitoxin and a "black powder" prepared by a traditional healer from ashes resulting from incineration of the biting puppet's tail. She did not receive any PEP.

The patient was transferred to the Gynaecology-Obstetrics University Clinic of the HKM National University Hospital in Cotonou for suspected rabies. Because of the strong suspicion of rabies and as the pregnancy was at full term (39 weeks of amenorrhea), it was decided to perform an emergency caesarean delivery. The patient received $10 \mathrm{mg}$ diazepam IM and 20 mg diazepam IV to allay anxiety and agitation, and the C-section was performed under classical general anaesthesia with tracheal intubation. A male child was extracted. Every 
effort was made to avoid contact between the mother's extraplacental tissues or fluids and the baby's mucous membranes (amniotomy after extraction of the head). The amniotic liquid was meconial. After suture of the uterus (hysterorraphy) and abdominal closure, the mother was transferred to the intensive care unit. She then progressed over a period of four days to febrile paraparesis, followed by paraplegia then tetraplegia requiring intubation. She died in the intensive care unit five days after delivery. Autopsy was denied by the relatives and the placenta could not be analysed due to traditional cultural norms in Benin. The case was notified to the health authorities.

The baby weighed $3370 \mathrm{~g}$ and measured $54 \mathrm{~cm}$ at birth. He was delivered in a state of apparent death, with an APGAR score of three at the first minute; but he rapidly improved and his APGAR score was six at the fifth minute, and 10 at the $10^{\text {th }}$ minute. He was fed with infant formula and grew well, with no symptom suggestive of rabies.

Due to logistical constraints (problems in vaccine and RIG procurement, compulsory authorization from the father who had to find resources for his transportation to Cotonou), it was 13 days before the newborn received rabies vaccine IM (Essen protocol at Days 0, 3, 7, 14 and 28 - vaccine: Verorab Sanofi Pasteur, batch K 1394-2) as well as equine RIG (Favirab Sanofi Pasteur, batch S 7046). All injections were delivered to the anterolateral aspects of the thighs. Tolerance was good, with a short fever episode $\left(38^{\circ} \mathrm{C}\right)$. The child is alive and in good health at seven months.

\section{Case 2 - Cambodia, Asia}

Early on October 8, 2013, a 33 year-old woman from Kompong Chhnang Province, Cambodia, presented to the local rural health centre with fever, hydrophobia and inability to drink, aerophobia, restlessness and difficulty breathing and sleeping. A couple of hours 
earlier, she had given birth to a healthy boy at her home, by vaginal delivery. Symptoms suggestive of rabies had progressively appeared during the 12 hours preceding delivery. Three months earlier, in early June 2013, while she was five months pregnant, she was bitten by a 3 month-old puppy on the second toe of the right foot and on the exterior aspect of the right ankle (Grade III exposure). The puppy appeared sick and bit another person (a child, no bleeding at bite site, lost to follow-up). It was put down and not laboratory-tested. The wound of the pregnant bite victim was cleaned using brake fluid and lemon. She received neither rabies PEP nor tetanus prevention.

On admission at the local health center, she received IV saline and was immediately referred to the Maternity ward of Kompong Chhnang Provincial Hospital, with mention of "hydrophobia". There, she received Ringer lactate infusion and diazepam and was referred to the Calmette reference hospital in Phnom Penh, the capital city, for suspected rabies. On arrival at the Calmette hospital on October 9, 2013, she was diagnosed as a probable rabies case according to WHO definition (11). She was neither further examined nor sampled for laboratory confirmation and was sent home, as no treatment can prevent death from rabies and death at home is preferred in Cambodia for cultural, religious and financial reasons. She died later that morning.

On October 9, the epidemiology staff of the Institut Pasteur Cambodia (IPC) was informed by contacts in Kompong Chhnang of this probable perinatal exposure to rabies. IPC requested the local health staff to perform a mouth swab on the corpse of the mother before traditional cremation, to obtain a post mortem saliva sample. The swab was tested at the IPC virology laboratory (rabies reference center) using an in-house reverse-transcriptase polymerase chain reaction assay, with primers well-suited to the region (12). The sample tested negative but this result remained questionable because of the clinical presentation, the very poor quality and 
insufficient quantity of the sample and the lack of demonstrated validity of this type of sampling (13). The case was notified to the health authorities.

IPC staff examined the newborn in Kampong Chhnang on October 10, 2013 (48h postdelivery) and administered PEP, injecting $0.66 \mathrm{ml}$ of Favirab equine RIG (lot J8427 exp. 08.2014) in the gluteal muscle $+0.1 \mathrm{ml}$ ID in each deltoid area with Verorab rabies vaccine (lot J1316-2 exp. 05-2015) following the modified Thai Red Cross schedule. The health center staff who had cared for the mother were immunized against rabies, as well as relatives who were to provide care for the newborn.

After written informed consent by the father, blood and saliva from the baby were sampled, at seven days and at one month. All tests were negative. The child is currently alive and well at 24 months.

\section{Review of the literature}

We performed a comprehensive search of other published cases of infants born to rabid mothers. Results are summarized in Table 1.

The outcomes of our two cases are discussed together with data from the published cases, in an attempt to gather evidence on the risk of rabies transmission from mother to child and to guide management of such cases.

\section{Discussion}

The two cases described above illustrate tragic events in Benin and Cambodia, caused by a disease which has been eliminated in developed countries but remains endemic - and neglected - in other parts of the world. There is little information available on mother-to-child RABV transmission and the risk for neonates born to rabid mothers. In the absence of 
recommendations, clinical teams lack evidence to handle such situations, e.g. measures to be taken, if any, to prevent rabies transmission to the infant, family members and healthcare staff.

Both newborns completed PEP, including RIG, initiated 13 days and 2 days after birth, respectively. Both remain healthy, after 9 months and 2 years, respectively. Had the mothers developed rabies? Laboratory diagnosis of rabies is rare in developing countries, because of problems in collecting brain samples for cultural reasons, healthcare worker awareness and training and a lack of competent laboratories, which contribute to the lack of reliable rabies epidemiological data (6). Nevertheless, the symptoms in the two mothers, including hydrophobia leading to death, both appearing in a compatible timeline with a documented history of a bite by a rabies-suspected animal, make the diagnosis of furious rabies highly probable according to WHO rabies clinical case definition (11).

This is also the case with most cases from the literature.

Can rabies virus be transmitted in utero or during delivery through contact with vaginal secretions or infected maternal tissues?

We identified publications since the beginning of the $20^{\text {th }}$ century describing 14 other cases of mothers dying of suspected or confirmed rabies shortly after delivery (18-31) (Table 1). We did not find the original article of the first published case (Case 0) (18), mentioned in two other papers $(19,20)$ reporting that injection of the child's medulla to a rabbit did not transmit rabies, while the mother's medulla did. As there was no information on delivery or PEP this case is excluded from the discussion below.

A single confirmed case of mother-to-child transmission of rabies has been reported, from Turkey (26). The infant, born to a mother with confirmed rabies, died of biologicallyconfirmed rabies 40 hours following provoked vaginal delivery. It is highly probable that vertical transmission occurred before birth as 40 hours would constitute an unusually short 
incubation period $(1,32,33)$. The other 14 children born from mothers with confirmed or probable rabies were all healthy at birth (Table 1).

Studies in animals suggest that RABV can be transmitted at birth, or shortly thereafter (e.g. in bats (34)). Bats, however, may not be a relevant model, as RABV infection does not invariably translate into disease in these animals, which are the main reservoir of RABV (35). Some cases of vertical transmission have been reported in ruminants and some other mammalian species $(36,37)$. Placentation, however, differs between ruminants (epitheliochorial) and humans (hemochorial placentation). Hemochorial placentation may contribute to prevent efficient transmission of RABV from the mother's tissues and fluids to the baby.

In an early study, placenta extracts collected after delivery of a rabid woman who delivered a healthy baby after C-section were found to be non-infectious (20). In another, similar case report, no evidence of rabies virus dissemination in utero was found (29). Placenta and umbilical cord specimens collected immediately after delivery were negative for RABV antigen detection by FAT and rapid rabies enzyme immuno-diagnosis, for virus isolation by mouse injection and in cell culture after four successive passages on murine neuroblastoma cells, and for viral RNA by nested RT-PCR (29).

\section{What then determines the risk?}

Peripartum transmission of other viral pathogens such as $\operatorname{HIV}(38,39)$ and $\operatorname{HBV}(40)$ is well documented. RABV circulation in the blood - of paramount importance in determining the transmission risk during exposure to blood or body fluids - is insignificant $(3,33,41)$. After inoculation by the bite of an infected animal, the virus replicates in the muscle close to the bite site and progresses along the axonal pathway to the brain where it replicates, protecting itself by maintaining the integrity of the brain-blood barrier. RABV can then spread along neural pathways to the heart, skin, and other organs, especially the salivary and serous glands 
of the tongue. All major neural and non-neural organs may contain significant amounts of virus $(3,33)$. Although experiments performed as early as 1804 showed that rabid humans' saliva injected to animals could cause rabies (42), exposure to other body fluids including blood seems to carry little or no risk.

\section{Cesarean or vaginal delivery?}

Timely and adequate treatment and/or elective caesarean section can significantly decrease peripartum transmission of bloodborne viruses (HIV (43); HBV (44)). Aside from the Turkish fatal case and excluding the first historical case, all other 14 children born from mothers with probable (8 cases) or laboratory-confirmed (6 cases) rabies (including the two cases described here), were healthy at birth, and all remained healthy at the time of reporting. Among these 14 healthy children, 5 were born by vaginal delivery, 2 of whom received PEP, and 9 children by C-section, 4 of whom received PEP. Based on this limited data, the route of delivery (vaginally or caesarean section) does not seem to affect outcome, reinforcing the notion that RABV is not readily transmitted by blood.

Should PEP be administered to protect infants born from rabid mothers?

Considering that rabies is always fatal, administration of PEP (RIG and vaccine) as soon as possible after birth seems appropriate, especially since there is no contraindication for PEP in infants (1). Cell-culture rabies vaccines are safe. In the two cases described here, PEP was well tolerated, with only a short episode of moderate fever in one case, confirming previous observations $(28,29)$. The ability of newborns to respond adequately to vaccines is well documented (45). Follow-up of the immune response in an infant vaccinated three days after birth showed high serum titres of both rabies neutralizing antibodies and specific anti-rabies glycoprotein IgG after immunization, (29). The absence of subcutaneous padding makes intradermal injection in the newborn challenging and injecting a full dose of vaccine in small muscles may cause pain. As there is no bite site, RIG should be administered in the gluteal 
muscle. Computing the necessary dose of RIG, however, can be challenging in children with low-birth weight.

We do not claim that the absence of transmission in the two cases described here is due to PEP: There was no laboratory confirmation of rabies in the mothers, nor in the biting animals; the delay between potential exposure and initiation of the PEP was of 2 and 13 days; and although the single well-documented fatal case had not received PEP (26), there is no clear evidence of frequent mother-to-child RABV transmission without PEP (Table 1).

Should healthcare workers who assisted the mother and family care-takers of the infant be vaccinated against rabies?

In the Cambodia case described above, rabies vaccination was provided to health care workers who cared for the patient and to close relatives who assisted the mother and were to care for the baby. This was done because of their perception of the risk of rabies rather than the transmission risk, which we considered nil. This may be an excessive use of PEP, but it was judged to be the best way to address their concerns and ensure that the baby would not lack care due to fear of rabies transmission.

Despite one single report of possible transmission to family members in Ethiopia (46), casual contact with a person with symptomatic rabies (touching unbroken skin or contact with body fluids such as urine, blood, and faeces) cannot readily transmit RABV to another person (47). The only well-documented cases of human-to-human RABV transmission occurred in recipients of transplanted corneas and other solid organs (with nerves) from donors in which rabies was not suspected $(48,49)$. According to WHO, close contact (mouth-to-mouth contact or kissing) and sexual intercourse in the early stages of the disease may potentially carry a risk for transmission (1). 
Although exposure of health care workers through direct contact of broken skin and/or mucosa may occur while caring for rabid patients (1), no such case has been published (50). Exposure to blood and body fluids can be avoided by observing standard precautions (51). WHO nevertheless recommends PEP in HCW considered to be at risk after careful assessment $(1,50)$.

\section{Limitations}

The results of our review must be considered with caution. The sparse available data make it impossible to state conclusively that RABV cannot be transmitted during delivery. Although peripartum transmission of RABV in humans seems exceptional, it remains possible considering the Turkish case. The number of cases studied is low; Rabies in the mother was laboratory-confirmed in only six cases, and six children received PEP shortly after birth and may therefore have been protected in spite of actual RABV transmission. Furthermore, follow-up of some cases may have been too short to conclude to absence of transmission.

Although the available data do not suffice to formulate definitive recommendations, they do provide good evidence for clinical teams to reassure grieving family members that the newborn will likely be spared. These favourable odds may be improved by caesarean section and by postnatal PEP, as a precautionary measure.

\section{Rabies could have been prevented in these pregnant women}

The fatalities in the mothers could have been prevented by PEP injected shortly after the dog bite. All modern rabies vaccines are inactivated, safe and potent, have no adverse effect on foetal development and can be administered to pregnant women or lactating mothers $(1,2,14$ 17).

In both cases described here, and in most of the published cases, bite victims were unaware of how to deal with animal bites in rabies-endemic countries, relying on traditional healers rather 
than referring to a hospital where they could have received life-saving PEP. Awareness of the need for prompt PEP administration to all individuals exposed to RABV must be promoted to spare human lives.

\section{Acknowledgements}

The authors wish to acknowledge and express their gratitude to those who helped access and/or translate rare resources: Gina G. Canceran, MLIS, University Librarian, UPM and Librarian-in charge, College of Medicine Medical Library, Manila, Philippines; Önder Ergönül, MD, MPH.

Professor of Infectious Diseases and Clinical Microbiology, Koç University, School of Medicine, Istanbul, Turkey ; Tamer Pehlivan, MD., MPH, Head of Medical Affairs Middle East \& North Africa Region, Sanofi Pasteur, Istanbul Turkey; Artem Metlin, DVM, PhD, Virology Unit, Institut Pasteur du Cambodge. The National Reference Centre for Rabies is

funded by the Institut de Veille Sanitaire, Saint-Maurice, France (http://www.invs.sante.fr/), by the General Direction of Health (Ministry of health) and the Institut Pasteur.

Potential conflicts of interest: B.D. has served as a consultant to Sanofi Pasteur No conflict of interest: other authors (C.T.A.; A.T.; E.Z.; S.G.; S.L.; P.A.; S.M.; H.B.; A.R.A.) 


\section{References}

1. WHO. WHO Expert Consultation on Rabies. Second Report. World Health Organization, Geneva; 2013. p. 54.

2. WHO. WHO position paper on rabies. Wkly Epidemiol Rec. 2010;85:309-20.

3. Hemachudha T, Ugolini G, Wacharapluesadee S, Sungkarat W, Shuangshoti S, Laothamatas

J. Human rabies: neuropathogenesis, diagnosis, and management. Lancet Neurol. 2013;12(5):498-513.

4. CDC. Human rabies prevention - United States, 2008. Recommendations of the Advisory

Committee on Immunization Practices. Morbid Mortal Wkly Rep. 2008;57((RR03)):1-26.

5. Warrell MJ, Warrell DA. Rabies: the clinical features, management and prevention of the classic zoonosis. Clin Med. 2015;15(1):78-81.

6. Hampson K, Coudeville L, Lembo T, Sambo M, Kieffer A, Attlan M, et al. Estimating the global burden of endemic canine rabies. PLoS Negl Trop Dis. 2015;9(4):e0003709.

7. Hampson K, Coudeville L, Lembo T, Sambo M, Kieffer A, Attlan M, et al. Correction: Estimating the global burden of endemic canine rabies. PLoS Negl Trop Dis. 2015;9(5):e0003786.

8. Knobel DL, Cleaveland S, Coleman PG, Fevre EM, Meltzer MI, Miranda ME, et al. Reevaluating the burden of rabies in Africa and Asia. Bull World Health Organ. 2005;83(5):360-8.

9. Carroll MW, Matthews DA, Hiscox JA, Elmore MJ, Pollakis G, Rambaut A, et al. Temporal and spatial analysis of the 2014-2015 Ebola virus outbreak in West Africa. Nature.

2015;524(7563):97-101.

10. Tarantola A, Ly S, In S, Ong S, Peng Y, Heng N, et al. Rabies Vaccine and Rabies Immunoglobulin in Cambodia: Use and Obstacles to Use. J Travel Med. 2015;22(5):348-52.

11. WHO. WHO recommended surveillance standards. Rabies. Second Edition.

WHO/CDS/CSR/ISR/99.2, 1999. Accessed:

http://www.who.int/csr/resources/publications/surveillance/WHO_CDS_CSR_ISR_99_2_EN/en/ 1999.

12. Mey C, Metlin A, Duong V, Ong S, In S, Horwood PF, et al. Evidence of two distinct phylogenetic lineages of dog rabies virus circulating in Cambodia. Infect Genet Evol. 2016;38:55-61. 13. Dacheux L, Wacharapluesadee S, Hemachudha T, Meslin FX, Buchy P, Reynes JM, et al. More accurate insight into the incidence of human rabies in developing countries through validated laboratory techniques. PLoS Negl Trop Dis. 2010;4(11):e765.

14. Sudarshan MK, Giri MS, Mahendra BJ, Venkatesh GM, Sanjay TV, Narayana DH, et al. Assessing the safety of post-exposure rabies immunization in pregnancy. Hum Vaccin. 2007;3(3):879.

15. Abazeed ME, Cinti S. Rabies prophylaxis for pregnant women. Emerg Infect Dis. 2007;13(12):1966-7.

16. Fayaz A, Simani S, Fallahian V, Eslamifar A, Hazrati M, Farahtaj F, et al. Rabies antibody levels in pregnant women and their newborns after rabies post-exposure prophylaxis. Iran J Reprod Med. 2012;10(2):161-3.

17. Huang G, Liu H, Cao Q, Liu B, Pan H, Fu C. Safety of post-exposure rabies prophylaxis during pregnancy: a follow-up study from Guangzhou, China. Hum Vaccin Immunother. 2013;9(1):177-83.

18. Krokiewicz. Wiener klinische Wochenschrift. 6 February 1902.

19. Babes V. Traité de la rage. Paris: Ballière; 1912 1912. 700 p.

20. Machado C, Zatz I, Saraiva P, JS G. [Observations or an infant born of a mother with rabies and subjected to preventive treatment by antirabies serum and vaccine]. Bulletin Société Pathologie Exotique. 1966;59:764-8.

21. Genevray J, Dodero J. Note sur un enfant né d'une mère en état de rage. . Ann Inst Pasteur. $1935 ; 55: 124-7$. 
22. Viazhevich VK. [Delivery of a normal infant from a mother in incubation period of rabies]. Zh Mikrobiol Epidemiol Immunobiol. 1957;28(7):105-6.

23. Relova RN. The hydrophobia boy. J Philipp Med Assoc. 1963;39:765-7.

24. Spence MR, Davidson DE, Dill GS, Jr., Boonthai P, Sagartz JW. Rabies exposure during pregnancy. Am J Obstet Gynecol. 1975;123(6):655-6.

25. Müller-Holve W, Leitritz H, Knorr E. [Early development of a child following rabies of the mother during pregnancy (author's transl)]. Infection. 1977;5(1):49-50.

26. Sipahioğlu U, Alpaut S. [Transplacental rabies in humans]. Mikrobiyoloji Bül. 1985;19:95-9.

27. Thongchaoren P, editor Rabies in Asia and in Thailand. In: Thongchaoren P, Kurstak E, eds. Virus diseases in Asia: Proceedings of the First International Conference on the Impact of Viral Diseases on the Development of Asian Countries. Bangkok (Dec 7-13, 1986). Bangkok, Akornsmai, pp. 63-72.1988.

28. Lumbiganon P, Wasi C. Survival after rabies immunisation in newborn infant of affected mother. Lancet. 1990;336(8710):319.

29. Iehle C, Dacheux L, Ralandison S, Rakoto Andrianarivelo M, Rousset D, Bourhy H. Delivery and follow-up of a healthy newborn from a mother with clinical rabies. J Clin Virol. 2008;42(1):82-5. 30. Swende TZ, Achinge GI. Clinical rabies in pregnancy with delivery of a live fetus: a case report. Niger J Med. 2009;18(1):114-5.

31. Mondal P, Char D, Mandal D, Das S. Rabies in a pregnant woman and delivery of a live fetus. Int J Gynaecol Obstet Off Organ Int Fed Gynaecol Obstet. 2014;125:171-2.

32. Dacheux L, Reynes JM, Buchy P, Sivuth O, Diop BM, Rousset D, et al. A reliable diagnosis of human rabies based on analysis of skin biopsy specimens. Clin Infect Dis. 2008;47(11):1410-7. 33. Hemachudha T, Laothamatas J, Rupprecht CE. Human rabies: a disease of complex neuropathogenetic mechanisms and diagnostic challenges. Lancet Neurol. 2002;1(2):101-9.

34. Constantine DG. Absence of prenatal infection of bats with rabies virus. Journal of wildlife diseases. 1986;22(2):249-50.

35. Amengual B, Bourhy H, Lopez-Roig M, Serra-Cobo J. Temporal dynamics of European bat Lyssavirus type 1 and survival of Myotis myotis bats in natural colonies. PLoS One. 2007;2(6):e566.

36. Martell MA, Montes FC, Alcocer R. Transplacental transmission of bovine rabies after natural infection. J Infect Dis. 1973;127(3):291-3.

37. Howard DR. Transplacental transmission of rabies virus from a naturally infected skunk. Am J Vet Res. 1981;42(4):691-2.

38. Siegfried N, van der Merwe L, Brocklehurst P, Sint TT. Antiretrovirals for reducing the risk of mother-to-child transmission of HIV infection. Cochrane Database Syst Rev. 2011(7):CD003510.

39. Lallemant M, Jourdain G, Le Coeur S, Mary JY, Ngo-Giang-Huong N, Koetsawang S, et al. Single-dose perinatal nevirapine plus standard zidovudine to prevent mother-to-child transmission of HIV-1 in Thailand. N Engl J Med. 2004;351(3):217-28.

40. Schillie S, Walker T, Veselsky S, Crowley S, Dusek C, Lazaroff J, et al. Outcomes of infants born to women infected with hepatitis B. Pediatrics. 2015;135(5):e1141-7.

41. Tarantola A, Abiteboul D, Rachline A. Infection risks following accidental exposure to blood or body fluids in health care workers: a review of pathogens transmitted in published cases. Am J Infect Control. 2006;34(6):367-75.

42. Fleming G. Rabies and hydrophobia: their history, nature, causes, symptoms, and prevention. London: Chapman and Hall; 1872.

43. Read J, Newell M. Efficacy and safety of cesarean delivery for prevention of mother-to-child transmission of HIV-1. Cochrane Database Syst Rev. 2005;CD005479.

44. Yang J, Zeng XM, Men YL, Zhao LS. Elective caesarean section versus vaginal delivery for preventing mother to child transmission of hepatitis B virus--a systematic review. Virol J. 2008;5:100. 45. Wood N, Siegrist CA. Neonatal immunization: where do we stand? Curr Opin Infect Dis. 2011;24(3):190-5.

46. Fekadu M, Endeshaw T, Alemu W, Bogale Y, Teshager T, Olson JG. Possible human-tohuman transmission of rabies in Ethiopia. Ethiop Med J. 1996;34(2):123-7.

47. GARC. Rabies exposure, prevention and treatment [30 October 2015]. Available from: https://rabiesalliance.org/rabies/what-is-rabies-and-frequently-asked-questions/exposure-preventiontreatment\#Can\%20people\%20transmit\%20rabies\%20to\%20other\%20people? 
48. CDC. Investigation of rabies infections in organ donor and transplant recipients--Alabama, Arkansas, Oklahoma, and Texas, 2004. Centers for Disease Control and Prevention. MMWR Morb Mortal Wkly Rep. 2004;53(26):586-9.

49. CDC. Update: investigation of rabies infections in organ donor and transplant recipients-Alabama, Arkansas, Oklahoma, and Texas, 2004. Centers for Disease Control and Prevention,. MMWR Morb Mortal Wkly Rep. 2004;53(27):615-6.

50. Kan VL, Joyce P, Benator D, Agnes K, Gill J, Irmler M, et al. Risk assessment for healthcare workers after a sentinel case of rabies and review of the literature. Clin Infect Dis. 2015;60(3):341-8. 51. Siegel JD, Rhinehart E, Jackson M, Chiarello L, Health Care Infection Control Practices Advisory C. 2007 Guideline for Isolation Precautions: Preventing Transmission of Infectious Agents in Health Care Settings. Am J Infect Control. 2007;35(10 Suppl 2):S65-164. 
Table 1: Published cases of perinatal rabies in parturients and outcome in newborns.

\begin{tabular}{|c|c|c|c|c|c|c|}
\hline No & Year & $\begin{array}{l}\text { City, } \\
\text { Country }\end{array}$ & Rabies signs in mother & Mother & Outcome & Reference \\
\hline 0 & 1902 & $\begin{array}{l}\text { Cracow, } \\
\text { Poland }\end{array}$ & $\begin{array}{l}\text { Dog bite history + clinical signs } \\
\text { and by rabbit inoculation }\end{array}$ & $\begin{array}{l}\text { Arrived rabid for delivery at } \\
9 \text { months }\end{array}$ & $\begin{array}{l}\text { EXCLUDED because of no } \\
\text { information on mode of } \\
\text { delivery or PEP; Died but no } \\
\text { transmission to experimental } \\
\text { rabbit }\end{array}$ & $\begin{array}{l}\text { Krokiewicz } 1902(18), \\
\text { quoted by Babes, } \\
1912 \\
\text { Machado et al, } 1966 \\
(19,20)\end{array}$ \\
\hline 1 & 1935 & $\begin{array}{l}\text { Hanoi, } \\
\text { Annam } \\
\text { (Vietnam) }\end{array}$ & $\begin{array}{l}\text { Dog bite history + clinical signs } \\
\text { and Negri bodies ; rabies in } \\
\text { inoculated rabbits }\end{array}$ & $\begin{array}{l}\text { Arrived rabid for delivery } \\
\text { "at term" }\end{array}$ & $\begin{array}{l}\text { C-section*, no PEP }{ }^{* *} \text {. Alive } \\
\text { and well at } 13 \text { months. }\end{array}$ & $\begin{array}{l}\text { Genevray (21)quoted } \\
\text { by Machado et al, } \\
1966 \text { (20) }\end{array}$ \\
\hline 2 & 1953 & $\begin{array}{l}\text { Novosibirsk, } \\
\text { Russia }\end{array}$ & $\begin{array}{l}\text { Dog bite history + diagnosis in } \\
\text { dog + clinical signs }\end{array}$ & Rabid 7 days after delivery. & $\begin{array}{l}\text { Vaginal delivery. No PEP. } \\
\text { Alive and well at } 2 \mathrm{yr} 8 \\
\text { months. }\end{array}$ & Viazhevich, 1957 (22) \\
\hline 3 & 1959 & $\begin{array}{l}\text { Manila, } \\
\text { Philippines }\end{array}$ & $\begin{array}{l}\text { Dog bite history + clinical signs + } \\
\text { rabies in inoculated mice }\end{array}$ & $\begin{array}{l}\text { Arrived rabid for delivery at } \\
9 \text { months. }\end{array}$ & $\begin{array}{l}\text { C-section. No PEP. Alive and } \\
\text { well at } 2 \frac{1}{2} 2 \text { years. }\end{array}$ & Relova, 1963 (23) \\
\hline 4 & 1964 & $\begin{array}{l}\text { Sao Paulo, } \\
\text { Brazil }\end{array}$ & $\begin{array}{l}\text { Dog bite history } 6 \text { months earliert } \\
\text { clinical signs and all exp. mice } \\
\text { died except when inoculated with } \\
\text { placental extract }\end{array}$ & $\begin{array}{l}\text { Arrived rabid (symptoms } \\
\text { for } 3 \text { days ) before delivery } \\
\text { at } 8 \text { months }\end{array}$ & $\begin{array}{l}\text { C-section and PEP (human } \\
\text { RIG** + vaccination); Alive } \\
\text { and well at } 2 \text { years }\end{array}$ & $\begin{array}{l}\text { Machado et al, } 1966 \\
(20)\end{array}$ \\
\hline 5 & 1972 & Thailand & $\begin{array}{l}\text { Dog bite history } 1 \text { month earlier + } \\
\text { clinical + signs + } \\
\text { immunofluorescence }\end{array}$ & Rabid 2 days after delivery & $\begin{array}{l}\text { Vaginal delivery. No PEP. } \\
\text { Alive and well at } 2 \text { years. }\end{array}$ & $\begin{array}{l}\text { Spence et al, } 1975 \\
(24)\end{array}$ \\
\hline 6 & 1975 & Lomé, Togo & $\begin{array}{l}\text { Dog bite history } 2.5 \text { months } \\
\text { earlier + clinical signs only }\end{array}$ & $\begin{array}{l}\text { Arrived rabid ( } 2 \text { days } \\
\text { earlier) for delivery at } 34 \\
\text { weeks }\end{array}$ & $\begin{array}{l}\text { Vaginal delivery, no PEP. } \\
\text { Alive and well at } 43 \text { weeks. }\end{array}$ & Müller-Holve (25) \\
\hline 7 & 1981 & $\begin{array}{l}\text { Ankara, } \\
\text { Turkey }\end{array}$ & $\begin{array}{l}\text { Dog bite history } 34 \text { days earlier + } \\
\text { clinical signs }\end{array}$ & Rabid before delivery & $\begin{array}{l}\text { Vaginal (induced) delivery. } \\
\text { No PEP. Died after } 40 \text { hours } \\
\text { of confirmed rabies. }\end{array}$ & Sipahioglu, 1985 (26) \\
\hline 8 & $\begin{array}{l}\text { Before } \\
1988\end{array}$ & Thailand & One case of maternal rabies & No information & $\begin{array}{l}\text { C-section. No PEP. No rabies } \\
\text { infection. }\end{array}$ & $\begin{array}{l}\text { Thongcharoen 1988, } \\
(27) \\
\text { cited by Lumbiganon, } \\
1990(28)\end{array}$ \\
\hline 9 & $\begin{array}{l}\text { Before } \\
1988\end{array}$ & Thailand & A second case of maternal rabies & No information & $\begin{array}{l}\text { C-section. No PEP. No rabies } \\
\text { infection. }\end{array}$ & $\begin{array}{l}\text { Thongcharoen 1988, } \\
\text { (27) } \\
\text { cited by Lumbiganon, } \\
1990(28)\end{array}$ \\
\hline 10 & 1987 & $\begin{array}{l}\text { Srinagarind, } \\
\text { Thailand }\end{array}$ & $\begin{array}{l}\text { Dog bite history } 3 \text { months earlier } \\
+ \text { clinical signs + Negri body in } \\
\text { dog's brain. }\end{array}$ & $\begin{array}{l}\text { Arrived rabid ( } 1 \text { day) for } \\
\text { delivery at } 40 \text { weeks }\end{array}$ & $\begin{array}{l}\text { Vaginal delivery + PEP at } \\
\text { birth. } \\
\text { Alive and well at } 2 \text { years } \\
\end{array}$ & $\begin{array}{l}\text { Lumbiganon, } 1990 \\
(28)\end{array}$ \\
\hline 11 & 2004 & $\begin{array}{l}\text { Antananariv } \\
0, \\
\text { Madagascar } \\
\end{array}$ & $\begin{array}{l}\text { Dog bite history } 1 \text { month earlier + } \\
\text { clinical signs }+ \text { rabies in } \\
\text { inoculated mice }\end{array}$ & $\begin{array}{l}\text { Arrived rabid for delivery at } \\
34 \text { weeks }\end{array}$ & $\begin{array}{l}\text { C-section, rabies PEP at D3, } \\
\text { no RIG. Alive and well at } 2 \\
\text { years. }\end{array}$ & lehlé et al, 2008 (29) \\
\hline 12 & 2009 & Niger & $\begin{array}{l}\text { Dog bite history } 7 \text { weeks earlier + } \\
\text { clinical signs }\end{array}$ & $\begin{array}{l}\text { Rabid before delivery at } 35 \\
\text { weeks }\end{array}$ & $\begin{array}{l}\text { C-section. No PEP. Alive and } \\
\text { well at } 5 \text { months. }\end{array}$ & $\begin{array}{l}\text { Swende et al, } 2009 \\
(30)\end{array}$ \\
\hline 13 & 2013 & Cambodia & $\begin{array}{l}\text { Dog bite history } 4 \text { months earlier } \\
\text { + clinical signs }\end{array}$ & $\begin{array}{l}\text { Rabid } 12 \text { hours before } \\
\text { delivery at } 38 \text { weeks }\end{array}$ & $\begin{array}{l}\text { Vaginal delivery + PEP (RIG } \\
\text { + vaccine). Alive and well at } \\
24 \text { months. }\end{array}$ & Present \\
\hline 14 & 2014 & $\begin{array}{l}\text { Bankura, } \\
\text { West } \\
\text { Bengal, } \\
\text { India }\end{array}$ & $\begin{array}{l}\text { Cat bite history } 4 \text { months earlier + } \\
\text { clinical signs }+ \text { biological } \\
\text { confirmation }\end{array}$ & $\begin{array}{l}\text { Rabid per delivery at } 34 \\
\text { weeks. }\end{array}$ & $\begin{array}{l}\text { C-section + PEP (RIG + } \\
\text { vaccine). Alive and well at } 6 \\
\text { months. }\end{array}$ & $\begin{array}{l}\text { Mondal et al, } 2014 \\
\text { (31) }\end{array}$ \\
\hline 15 & 2015 & $\begin{array}{l}\text { Cotonou, } \\
\text { Benin }\end{array}$ & $\begin{array}{l}\text { Dog bite history } 1 \text { month earlier + } \\
\text { clinical signs }\end{array}$ & $\begin{array}{l}\text { Rabid per delivery at } 39 \\
\text { weeks. }\end{array}$ & $\begin{array}{l}\text { C-section + PEP (RIG+ } \\
\text { vaccine). Alive and well at } 7 \\
\text { months. }\end{array}$ & Present \\
\hline
\end{tabular}

*C-section: caesarean section / caesarean delivery

**PEP: post-exposure prophylaxis (vaccine only); RIG: rabies immunoglobulin 